\title{
Twelve invertebrate and eight fish species new to the marine fauna of Madeira, and a discussion of the zoogeography of the area
}

\author{
Peter Wirtz \\ Centro de Ciências Biológicas e Geológicas, Universidade da Madeira, \\ Largo do Colégio, $P$ - 9000 Funchal, Portugal, Madeira
}

\begin{abstract}
The benthic ctenophore Vallicula multiformis, a large undescribed flatworm species of the genus Pseudoceros, the prosobranch gastropod Tonna maculosa, the opisthobranch gastropods Placida cf. dendritica, Caloria elegans, Aeolidiella sanguinea, Janolus cristatus, the decapod Balssia gasti, the sea urchin Schizaster canaliferus and the tunicates Clavelina lepadiformis, Clavelina dellavallei and Pycnoclavella taureanensis are recorded from Madeira for the first time. This is the first record of a platyctenid ctenophore in the eastern Atlantic. The teleost fishes Pomatoschistus pictus, Vaneaugobius canariensis, Chromogobius sp., Nerophis ophidion, Hippocampus hippocampus, Acanthocybium solandri, Sphyraena viridensis and Sphyraena barracuda are recorded from Madeira for the first time. The presence of the sea-hare Aplysia dactylomela at Madeira is confirmed; the species has increased tremendously in abundance in the last four years. The crocodile fish Grammoplites gruveli can occasionally be found in the mantle cavity of cuttlefish (Sepia officinalis) sold at the fish market of Funchal, but does not originate from Madeiran waters. An analysis of 100 new records from the coastal fauna of Madeira shows that, while predominantly of lusitanian, mediterranean and mauritanian affinity, Madeira's shallow water fauna contains a large component of tropical species.
\end{abstract}

\section{INTRODUCTION}

During an ongoing survey of the larger marine vertebrates and invertebrates of the coasts of Madeira (Biscoito \& Wirtz, 1994; Wirtz, 1994, 1995a, 1995b; Wittmann \& Wirtz, in press), several species were encountered that apparently had not yet been recorded from Madeira. Twenty of these are described in this paper. A large number of Hydrozoa, Nudibranchia and Decapoda, all new for the marine fauna of Madeira and including several undescribed species, will be treated in separate publications by experts for these groups.

\section{MATERIAL AND METHODS}

The survey is performed by SCUBA-diving and therefore limited to a depth range down to about $60 \mathrm{~m}$. Animals are photographed in the field. When it appears necessary, specimens are then collected for later identification. In most cases, preserved specimens are sent to specialists for identification or confirmation of identification (see "Acknowledgements").

Voucher specimens of all species were deposited in the collection of the Museu Mu- 
nicipal (Historia Natural) of Funchal, except for the following: the single specimen of Aeolidiella sanguinea is in the collection of the Zoology Laboratory of the University of Oviedo, Spain; Hippocampus hippocampus and Sphyraena viridensis were documented by underwater photography (slides deposited in the Museu Municipal of Funchal); Acanthocybium solandri was documented by numerous photos of the fish plus the person having captured it (one such photo was deposited in the Museu Municipal of Funchal). Apparently, neither photos nor preserved specimens exist, as yet, of Sphyraena barracuda from Madeiran waters.

\section{RESULTS}

\section{Ctenophora Platyctenida}

Vallicula multiformis Rankin, 1956

A creeping ctenophore can commonly be encountered at night on algae such as Zonaria tournefortii in depths of 5 to $15 \mathrm{~m}$ during the summer months. The species obviously belongs to the genus Vallicula Rankin 1956. Vallicula multiformis is the only known species in this genus and the specimens from Madeira perfectly correspond to the description of the species as given by Rankin (1956).

Animals were seen clinging to the tips of the algae only under conditions of (moderate) water movement. V. multiformis probably needs water flow for passive extension of its tentacles (Emson \& Whitfield, 1991). Voucher specimens have been deposited not only in the Museu Municipal (História Natural) in Funchal but also in the Nationaal Natuurhistorisch Museum in Leiden and the Natural History Museum in London.

The species has so far only been recorded from the Western Atlantic (Freeman, 1967; Rankin, 1956; Sterrer, 1986). The finding of $V$. multiformis in Madeiran waters represents the first record of a platyctenid ctenophore from the eastern Atlantic.

\section{Plathelminthes Polycladida}

Pseudoceros sp.

A large, colourful, and apparently undescribed flatworm of the genus Pseudoceros can occasionally be found when turning over stones in a depth range of (at least) 10 to $20 \mathrm{~m}$ along the south coast of Madeira. Individuals usually are three to six $\mathrm{cm}$ long. Apparently, no other species in the genus Pseudoceros has the colour pattern of golden and white lines on a pitchblack body. A colour photo of an individual of this species collected near Caniço, south coast of Madeira, in $12 \mathrm{~m}$ depth is given in Wirtz (1995a, page 69 bottom).

The species also occurs in the Canary Islands: a colour photo of the same species is given in Pérez Sánchez \& Moreno Batet (1991, page 101).

\section{Mollusca Gastropoda}

Tonna maculosa (Dillwyn, 1810)

A shell of this species, measuring approximately $14 \mathrm{~cm}$ in height and $9 \mathrm{~cm}$ in diameter, was collected in about $10 \mathrm{~m}$ depth in front of Madeira airport. There is a small 
Twelve invertebrate and eight fish species new to the marine fauna of Madeira 199

borehole near the tip, otherwise the shell is in perfect condition. While the finding of a molluscan shell cannot be definitive proof of the existence of live animals in the area, it seems unlikely that anybody would have transported the shell to Madeira and then discarded it.

The species lives in the Western Atlantic (Caribbean to Bermuda) and has occasionally been found along the west African coast and in the Canary Islands (Sterrer, 1986; Poppe \& Goto, 1991).

Placida cf. dendritica (Alder \& Hancock, 1843)

The species was common on the green alga Codium decorticatum in about 2-6 $\mathrm{m}$ depth in the shallow and very protected bay of Reis Magos, southeastern coast of Madeira, beginning of May 1995. Nine weeks later most of the C. decorticatum had disappeared and no Placida could be found any more. In May and June 1996, the species was again common on $C$. decorticatum at Reis Magos and Säo Pedro, southeastern coast of Madeira. In May 1996 it was also found to be common on Codium tomentosum at Porto Novo and in August 1996 on Codium adhaerens at Caniço.

Placida dendritica is a cosmopolitan species living on several species of the green alga Codium; in the eastern Atlantic it has previously been recorded from Norway to the Mediterranean (Millen, 1980; Gosliner, 1987; Thompson, 1988; Trowbridge, 1995).

\section{Caloria elegans (Alder \& Hancock, 1845)}

Large numbers of this species were seen crawling over rocks in about $9 \mathrm{~m}$ depth at Porto da Cruz, north coast of Madeira, end of March and end of April 1996; middle of May, no more animals were seen in the same area.

Caloria elegans is considered a boreal species (Cattaneo-Vietti et al., 1990) and has previously been recorded from Great Britain into the Mediterranean (Thompson, 1988). The colour photo in Wirtz (1995a, page 183) shows an individual from Faial Island, Azores.

\section{Aeolidiella sanguinea Norman, 1877}

A single individual of this species was found when turning over stones at a depth of $9 \mathrm{~m}$ at Caniçal, southeastern coast of Madeira. This is the animal figured in a colour photo on page 183 in Wirtz (1995a).

Aeolidiella sanguinea is a boreal species, common around the British Isles and previously recorded as far south as the Strait of Gibraltar (Garcia-Gomez et al., 1989). Finding the species at Madeira represents a considerable range extension.

\section{Janolus cristatus (Delle Chiaje, 1841)}

Two adult animals of this species were seen close together on a rock in about $9 \mathrm{~m}$ depth at Porto da Cruz, north coast of Madeira, end of April 1996.

The species has previously been recorded from the Mediterranean Sea and from south Norway to Morocco in the eastern Atlantic (Thompson, 1988; Cattaneo-Vietti et al., 1990).

\section{Aplysia dactylomela Rang, 1828}

The annulated sea-hare has a circumtropical distribution (Gronow \& Hayward, 1991; Ortea \& Martinez, 1991). It has already been recorded from Madeira by Watson (1897). The only other reference to the presence of this species at Madeira was by Nobre (1937). 
Since then, the species has never again been mentioned from Madeira. During several hundred dives around the island from 1983 until 1993, the author never encountered this large sea-hare. Aplysia dactylomela was definitely absent from the area near Ponta Oliveira, south coast of Madeira, during the years 1989 to 1993. The species was first recorded in shallow water (5-10 m depth) near Ponta Oliveira in 1994 and is now common there. An animal of about $20 \mathrm{~cm}$ length was observed spawning in about $4 \mathrm{~m}$ water depth near Reis Magos, south coast of Madeira island on 30 May 1997.

\section{Crustacea Decapoda}

Balssia gasti (Balss, 1921)

Balssia gasti is common on the zoantharian Gerardia savaglia, that frequently grows on Antipathes bushes and on old pieces of Antipathes skeletons on the south coast of Madeira. When wiping bushes of Gerardia with a small handnet at depths greater than $25 \mathrm{~m}$ (but not when searching shallower), this decapod was frequently encountered. Noel (1992) recognizes two different European species in the genus Balssia; according to his key, Madeiran specimens belong to the species $B$. gasti as they have three large spines on the cephalothorax. Voucher specimens have been deposited not only in the Museu Municipal (História Natural) at Funchal but also in the Nationaal Naturrhistorisch Museum at Leiden.

Balssia spp. live associated with various anthozoans and sponges in the Mediterranean sea and in the Eastern Atlantic from north-eastern Morocco and the Canary Islands to Guinea (Zibrowius, 1985; Noel, 1992; Mori et al., 1994; González Pérez, 1995; Ocana et al., 1995).

\section{Echinodermata Echinoidea}

Schizaster canaliferus (Lamarck, 1816)

An empty test of Schizaster canaliferus was found in about $12 \mathrm{~m}$ depth on sandy bottom in front of Ponta Santa Caterina, southeastern coast of Madeira in May 1996. The species has up to now been considered a Mediterranean endemic (Schinner, 1993).

\section{Tunicata Ascidiacea}

\section{Clavelina lepadiformis (Müller, 1776)}

Clavelina lepadiformis (in its typical white-rimmed form) can occasionally be found in the area around Funchal. The species is not at all common. C. lepadiformis has probably been transported to the Azores by boats (Monniot, 1974; Monniot \& Monniot, 1983) where it has subsequently spread (Wirtz \& Martins, 1993). C. lepadiformis may also have been transported to Madeira by boats. The photos of C. lepadiformis in Wirtz (1995a, page 221) and Wirtz (1996a, page 162/163) are from Azorean animals.

Much more common at Madeira is a tunicate that may be a yellow form of $C$. lepadiformis (cf. colour photo in Wirtz, 1996a page 162). According to Brunetti (1987), the yellow pigmentation of $C$. lepadiformis present in north European seas also exists but is uncommon in the Mediterranean Sea. I do, however, suspect that the yellow-rimmed Clavelina of Madeira is a different species, because, unlike C. lepadiformis, these ani- 
Twelve invertebrate and eight fish species new to the marine fauna of Madeira 201

mals are restricted to dark places such as cave entrances and overhangs. It is, of course, also possible, that the yellow form is the indigenous one, while the white form has been introduced fairly recently.

C. lepadiformis has been recorded from the Mediterranean Sea and in the eastern Atlantic from western Norway as far south as the Canary Islands (Millar 1966; Pérez Sánchez \& Moreno Batet, 1991; Wirtz \& Martins, 1993).

Clavelina dellavallei (Zirpolo, 1925)

This species is common from low water spring tide level down to at least $6 \mathrm{~m}$ depth all around Madeira. Photos of Madeiran animals are given in Wirtz (1995a, page 223, photo by P. Gomes) and in Wirtz (1996a, page 164).

The species has so far been considered a Mediterranean endemic (Brunetti, pers. comm.) but Templado et al. (1993) have already reported it from the eastern Atlantic just outside the Strait of Gibraltar.

\section{Pycnoclavella taureanensis Brunetti, 1991}

This species is very common at Madeira, down to at least $45 \mathrm{~m}$ depth. Photos of Madeiran animals are given in Wirtz (1995a, page 221) and in Wirtz (1996a, page 164).

Recently described, the species has so far only been reported from the western Mediterranean.

\section{Osteichthyes Teleostei}

Pomatoschistus pictus (Malm, 1865)

The painted goby is common on the south coasts of Madeira and of Porto Santo, where it occurs on sandy bottom, frequently close to rock walls, at depths from 10 to at least $40 \mathrm{~m}$. Photos of Madeiran animals are given in Wirtz (1996b, page 238).

The species has been recorded from the Mediterranean Sea and in the eastern Atlantic from Norway to the Canary Islands (Miller, 1990).

Vaneaugobius canariensis Van Tassel, Miller \& Brito, 1987

A population of this species was encountered on sandy-muddy bottom in about 10-20 m depth on the eastern side of the bay of Machico, south coast of Madeira. Photos of Madeiran animals are given in Wirtz (1996b, page 239). Specimens have been deposited in the Museu Municipal (História Natural) Funchal and in the Naturkundemuseum Stuttgart.

The species has previously been recorded from the Canary Islands and from Guinea (Miller, 1990).

\section{Chromogobius sp.}

This small goby was collected from cracks and crevices in caves in 10-20 m depth at the south coast of Madeira and from below a stone in $25 \mathrm{~m}$ depth at Porto Santo island. The animals clearly belonged to the genus Chromogobius. P. J. Miller (pers. comm.) informed me that James van Tassel of the American Museum of Natural History is currently describing a new species of this genus from the Canary Islands. J. van Tassel kindly sent me a preliminary version of his manuscript and from this it is evident that the Madeiran 
species is the same as the undescribed Canarian species. Photos of Madeiran animals are given in Wirtz (1996b, page 239).

The species has so far only been recorded from the Canary Islands (Miller, 1990, as Chromogobius sp.).

Nerophis ophidion (Linnaeus, 1758)

A single individual of this species was caught in a Cymodocea nodosa meadow in the western half of the bay of Machico in about $12 \mathrm{~m}$ depth in September 1995.

The species has previously been recorded from the Mediterranean Sea and in the eastern Atlantic from Norway as far south as the Canary Islands (Dawson, 1986; Brito, 1991).

Hippocampus hippocampus (Linnaeus, 1758)

Both European species of seahorses, Hippocampus hippocampus (Linnaeus, 1758) and Hippocampus ramulosus Leach, 1814 are common at Madeira, but only H. ramulosus has so far been noted in the literature. The photo of a Madeiran animal in Wirtz (1994, page 49) does in fact show $H$. hippocampus and not $H$. ramulosus, as erroneously stated.

Hippocampus hippocampus has been recorded from the Mediterranean Sea and in the eastern Atlantic from the Wadden Sea south to the Gulf of Guinea (Dawson, 1986).

\section{Acanthocybium solandri (Cuvier, 1831)}

The Wahoo is occasionally sold at Funchal fish market ("Mercado dos Lavradores"). Enquiring about the origin of these fish, I was told that they came from Madeiran waters. To check on this, I interviewed the sportsfisherman community and was told the following: Wahoo are not uncommon in late summer; it seems that these fish migrate from the south with warmer water, as in some years they hardly appear at all, particularly when the water is unseasonably cold (R. Hayes and M. Henriquez, pers. comm.). Numerous photos document the capture of this species. Nevertheless, Acanthocybium solandri has not yet been recorded from Madeira in the scientific literature and the FAO species catalogue summarizing our knowledge on the scombrids of the world (Collette \& Nauen, 1983) notes the presence of this species at the Cape Verde Islands, but not at the Canary Islands, where it is of considerable economic importance. The species has recently also been recorded from the Azores (Azevedo \& Heemstra, 1995).

\section{Sphyraena viridensis (Cuvier, 1829)}

The only barracuda reported from Madeiran waters until now is the European Barracuda Sphyraena sphyraena (Linnaeus, 1758). As noted by Ben-Tuvia (1986) and de Silva (1990) the Striped Barracuda Sphyraena viridensis has in the past frequently been confused with Sphyraena sphyraena. Brito (1991) already noted that $S$. sphyraena probably does not occur at the Canary Islands and that all previous records of this species at the Canaries are probably misidentifications of the very common $S$. viridensis. This is apparently also true for the Azores (Wirtz, 1990: unpublished report to the Departamento de Oceanografia e Pescas of the University of the Azores) and for Madeira: During several hundred dives at both these archipelagos I have seen and photographed $S$. viridensis quite frequently, while never encountering $S$. sphyraena. The specimen reported as Sphyraena sphyraena in Edwards (1993) was checked and confirmed to be $S$. viridensis (Edwards, pers. comm.). 
Twelve invertebrate and eight fish species new to the marine fauna of Madeira 203

Sphyraena viridensis is also known from the Mediterranean Sea, but because of past confusion with $S$. sphyraena the distribution of this species is insufficiently documented (de Silva, 1990; Bizsel \& Cihangir, 1996).

\section{Sphyraena barracuda (Walbaum, 1792)}

The Greater Barracuda Sphyraena barracuda has a large distribution in the Atlantic, the Indian Ocean, and the Pacific (de Silva, 1990). In the eastern Atlantic it is considered rare and known with certainty only from Senegal to Nigeria (de Silva, 1990). When interviewing the sportsfisherman community in Funchal harbour (see section on Acanthocybium solandri, above), I was told that, while the Greater Barracuda is extremely rare, large individuals of this species have been caught near Madeira ( $R$. Hayes and $M$. Henriquez, pers. comm.). Unfortunately, there seems to be no photo to document this.

\section{Grammoplites gruveli (Pellegrin, 1905)}

When buying cuttlefish (Sepia officinalis) at Funchal fish market ("Mercado dos Lavradores") the author encountered twice, in 1994 and in 1996, an individual of the crocodile fish Grammoplites gruveli in the mantle cavity of the cuttlefish. The fishermen selling the cuttlefish had, however, not caught it themselves. They had bought the cuttlefish from a firm that had boats catching them in the area of Guinea-Bissao. Thus, $G$. gruveli cannot be counted as a Madeiran fish.

The species has so far been recorded from Mauritania to Angola (Knapp, 1990).

\section{DISCUSSION}

Each newly recorded species can be considered a test case for the theories on the zoogeography of the area in question. In recent publications (Wirtz et al., 1988; Abreu, 1991; Abreu, 1994; Abreu \& Biscoito, 1994; Biscoito \& Wirtz, 1994; Guerreiro, 1994; Houart \& Abreu, 1994; Stock, 1994; Wirtz, 1994, 1995 a, 1995 b; Knight-Jones \& Knight-Jones, 1995; Malaquias, 1996; Núnez et al., 1995; Núnez \& Talavera, 1996; Ortea et al., 1996; Rogers \& Nash, 1996; d'Udekem d'Acoz, 1996; Valdés et al., 1996; Wittmann \& Wirtz in press) and in this one, a total of 134 species has been newly recorded for the shallow water marine fauna of Madeira and the neighbouring island of Porto Santo (several more, apparently undescribed species have been found recently and were sent to specialists for description). For 30 of these, I was unable to find precise data on their distribution. Four species found exclusively in or near harbours and thus probably transported by man are excluded from the following analysis. Table 1 summarizes the known distribution of the remaining 100 species, using the terminology of Briggs (1974).

The largest part of the species belongs to the area of which Madeira is an integral part, the Mediterranean-Atlantic region (consisting of the Lusitanian, the Mediterranean and the Mauritanian province). An additional 9 species have the same distribution but extend south into west African waters. A strong tropical influence on the marine fauna of Madeira has been noted previously (Wirtz, 1994, 1995b). The three tropical components $(18 \%)$, the intermediate component $(9 \%)$ and the atlanto-mediterranean component $(24 \%)$ thus form the bulk (51\%) of the recent additions to the Madeiran shallow-water fauna. With $19 \%$, a boreal influence (species occurring as far north as Norway, some of 
Table 1. Zoogeographic affinity of 100 animal species recently recorded from the shallow waters of Madeira

$\begin{array}{lr}\text { Currently only known from Madeira } & 7 \\ \text { Currently only known from Madeira and the Canary Islands } & 9 \\ \text { Currently only known from Madeira, the Canary Islands and the Azores } & 2 \\ \text { Cosmopolitan } & 11 \\ \text { Eastern Atlantic boreal } & 19 \\ \text { Lusitanian, Mediterranean and Mauritanian } & 24 \\ \text { Lusitanian, Mediterranean, Mauritanian and West African } & 9 \\ \text { Tropical a) eastern Atlantic } & 2 \\ \text { b) amphi-Atlantic } & 9 \\ \text { c) circumtropical } & 7 \\ \text { Tropical amphi-Atlantic and eastern Atlantic Lusitanian and eastern Atlantic Boreal } & 1\end{array}$

those extending into the western Mediterranean) is also quite strong. Adding to this a substantial component of cosmopolitan species (11\%; but see Knowlton, 1993 and Miya \& Nishida, 1997 on the probability that many so called cosmopolitan species are unrecognized complexes of sibling species), the picture that emerges is that of a multiple origin of the Madeiran shallow water biota.

Bianchi et al. (in press) have pointed out that tropical species are the dominant species in two sublittoral communities. They also discussed the possibility of a recent warming trend influencing and changing the shallow water faunal and floral composition of Madeira. The increase of the abundance of the circumtropical sea-hare Aplysia dactylomela on the coast of Madeira, which undoubtedly is a recent phenomenon, is another indicator that the shallow water biota of Madeira might be in a phase of change.

Acknowledgments. Pedro Gomes from the SCORPIO SCUBA diving base at the Lido do Funchal showed me an underwater photo of Vallicula multiformis and went diving with me to collect the animals. Ronald Emson (King's College, London) confirmed my identification of Vallicula multiformis. Alex Rogers (Plymouth Marine Lab, UK) confirmed that the Pseudoceros apparently is an undescribed species. Gonzales Rodriguez (Oviedo University, Spain) and Lucas Cervera (Cadiz University, Spain) identified Aeolidiella sanguinea. António Malaquias (Museu Municipal, Historia Natural, Funchal) provided opistobranch references. António Domingos (Museu Municipal, Historia Natural, Funchal) confirmed the identification of Tonna maculosa and cautioned on using the finding of shells for evidence of the distribution of a species. Ricardo Brunetti (Padua University, Italy) identified Pycnoclavella taureanina and confirmed the identification of Clavelina dellavallei. R. Hayes and M. Henriquez helped me with information about the fish species caught by sportsfishermen in Madeiran waters. Silja Swaby (Plymouth) drew my attention to the misidentification of Hippocampus in my book on the fishes of Madeira. Alasdair Edwards checked the identity of the Madeiran Sphyraena in the Hancock Museum. Manuel Biscoito elucidated the origin of the Grammoplites gruveli found at Funchal fish market. Nike Bianchi, Manuel Biscoito, Lucas Cervera and Carla Morri commented on an early draft of the manuscript. Many thanks to all of them. 
Twelve invertebrate and eight fish species new to the marine fauna of Madeira 205

\section{LITERATURE CITED}

Abreu, A. D., 1991. First record of Mitra zonata Mayrrat, 1818 and Cancilla turtoni (Smith, 1890) (Gastropoda: Mitridae) from the archipelago of Madeira. - Bocagiana 142, 1-2.

Abreu, A. D., 1994. On the presence of Mitrella pallaryi (Dautzenberg, 1927) (Mollusca: Gastropoda) in the archipelago of Madeira. - Bocagiana 172,1-4.

Abreu, A. D. \& Biscoito, M. J., 1994. The family Cassidae (Mollusca: Gastropoda) in the archipelago of Madeira. - Bocagiana 164, 1-3.

Azevedo, J. M. \& Heemstra, P. C., 1995. New records of marine fishes from the Azores. Arquipélago. Life Mar. Sci. 13 A, 1-10.

Ben-Tuvia, A., 1986. Sphyraenidae. In: Fishes of the North-eastern Atlantic and the Mediterranean. Ed. by P. J. P. Whitehead, M. L. Bauchot, J. C. Hureau, J. Nielsen \& E. Tortonese. UNESCO, Paris, $1473 \mathrm{pp}$.

Biscoito, M. \& Wirtz, P., 1994. Two new records of stingrays (Pisces Dasyatidae) from the archipelago of Madeira (NE Atlantic). - Bocagiana 169, 1-4.

Bizsel, K. \& Cihangir, B., 1996. A new fish record from the Turkish seas $i$ yellow-mouth barracuda (Sphyraenidae; Sphyraena viridensis Cuvier, 1829. - Turkish J. Zool. 20, 357-359.

Briggs, J. C., 1974. Marine zoogeography. McGraw-Hill, New York, 475 pp.

Brito, A., 1991. Catálogo de los peces de las islas Canarias. F. Lemus, La Laguna, 230 pp.

Brunetti, R., 1987. Species of Clavelina in the Mediterranean Sea. - Annls Inst. océanogr., Paris 63, $101-118$

Brunetti, R., 1991. Pycnoclavella taureanina n.sp. (Ascidiacea) from the Mediterranean Sea. - Vie Milieu 41, 245-248.

Cattaneo-Vietti, R., Chemello, R. \& Gianuzzi-Savelli, R., 1990. Atlas of Mediterranean nudibranchs. Editrice La Conchiglia, Roma, $264 \mathrm{pp}$.

Collete, B. \& Nauen, C. E., 1983. FAO species catalogue. Vol. 2. Scombrids of the world. - FAO Fish. Synops. 125(2), 1-137.

Dawson, C. E., 1986. Syngnatidae. In: Fishes of the North-eastern Atlantic and the Mediterranean. Ed. by P. J. P. Whitehead, M. L. Bauchot, J. C. Hureau, J. Nielsen \& E. Tortonese. UNESCO, Paris, $1473 \mathrm{pp}$.

Edwards, A. J., 1993. A small collection of fishes from Madeira Island deposited in the Hancock Museum. - Trans. nat. Hist. Soc. Northumbria 56, 35-40.

Emson, R. J. \& Whitfield, P. J., 1991. Behavioural and ultrastructural studies on the sedentary platyctenean ctenophore Vallicula multiformis. - Hydrobiologia 216/217, 27-33.

Freeman, G., 1967. Studies on regeneration in the creeping ctenophore, Vallicula multiformis. - J. Morphol. 123, 71-83.

Garcia-Gomez, J. C., Cervera, J. L., Garcia, F. J. \& Cuadra, C. L. M., 1989. Resultados de la Campaña Internacional de Biologia Marina "Ceuta 86": Moluscos Opistobranquios. - Boll. malac. 25, $125-138$.

González Pérez, J. A., 1995. Crustáceos decápodos de las Islas Canarias. Publicaciones Turquesa, Santa Cruz de Tenerife, $282 \mathrm{pp}$.

Gosliner, T., 1987. Nudibranchs of Southern Africa. Sea Challengers, Monterey, 136 pp.

Guerreiro, J., 1994. On bivalve molluscs of the island of Porto Santo (Madeira, Portugal). - Bocagiana $173,1-4$.

Gronow, N. \& Hayward, P. J., 1991. Opisthobranches de l'île Maurice, avec la description de deux espèces nouvelles. - Revue fr. Aquariol. 18, 1-30.

Houart, R. \& Abreu, A. D., 1994. The Muricidae (Gastropoda) from Madeira with the description of a new species of Ocenebra (Ocinebrina) (Muricidae: Ocenebrinae). - Apex 9, 119-130.

Knapp, L. W., 1990. Platycephalidae. In: Check-list of the fishes of the eastern tropical Atlantic. Ed. by J. C. Quéro, J. C. Hureau, C. Karrer, A. Post \& L. Saldanha. UNESCO, Lisbon, 1492 pp.

Knight-Jones, P. \& Knight-Jones, E. W., 1995. Spirorbidae (Polychaeta) from Madeira including a new species and subgenus of Spirorbis. - Mitt. hamb. zool. Mus. Inst. 92, 89-101.

Knowlton, N., 1993. Sibling species in the sea. - A. Rev. Ecol. Syst. 24, 189-216.

Malaquias, M. A. E., 1996. Opisthobranquios (Mollusca Gastropoda) do arquipélago da Madeira e ilhas Selvagens. Relatório de estágio, Universidade da Algarve, Faro, $72 \mathrm{pp}$.

Miya, M. \& Nishida, M., 1997. Speciation in the open ocean. - Nature, Lond. 389, 803-804. 
Millar, R. H., 1966. Tunicata-Ascidiacea. Marine invertebrates of Scandinavia 1, 1-123.

Millen, S. V., 1980. Range extensions, new distribution sites, and notes on the biology of sacoglossan opisthobranchs (Mollusca: Gastropoda) in British Columbia. - Can. J. Zool. 58, 1207-1208.

Miller, P. J., 1990. Gobiidae. In: Check-list of the fishes of the eastern tropical Atlantic. Ed. by J. C. Quéro, J. C. Hureau, C. Karrer, A. Post \& L. Saldanha. UNESCO, Lisbon, 1492 pp.

Monniot, C. \& Monniot, F., 1983. Navigation ou courants ? La colonisation des Açores et des Bermudes par les ascidies (Tuniciers benthiques). - C. r. Soc. Biogéogr. 59, 53-58.

Monniot, F, 1974. Ascidies littorales e bathyales récoltées au cours de la campagne Biacores: Aplousobranches. - Bull. Mus. natn. Hist. nat., Paris ( $3^{\mathrm{e}}$ sér. $\mathrm{n}^{\circ} 251$, Zoologie) $173,1287-1326$.

Mori, M., Morri, C. \& Bianchi, C. N., 1994. Notes on the life history of the pontonine shrimp Balssia gasti (Balss, 1921). - Oebalia 20, 129-137.

Nobre, A., 1937. Moluscos Testáceos Marinhos do Arquipélago da Madeira. Mems Estud. Mus. zool. Univ. Coimbra (Ser. 1) 98, 1-101.

Noel, P., 1992. Clé préliminaire d'identification des Crustacea Decapoda de France et des principales autres espèces d'Europe. - Coll. patrimoines nat. Secrétariat de la Faune et de la Flore. Mus. Nat. d'Hist. Naturelle, Paris, 9, 1-145.

Núnez, J., Pascual, M., Delgado, J. D. \& San Martín, G., 1995. Interstitial polychaetes from Madeira, with a description of Syllides bansei Perkins, 1981. - Bocagiana 179, 1-7.

Núnez, J. \& Talavera, J. A., 1996. Fauna of the polychaetous Annelida from Madeira. - Bolm Mus. Mun. Funchal (Supl.) 4, 511-530.

Ocana, O., Brito, A., Núnez, J. \& Bacallado, J., 1995. Redescripción de Gerardia savaglia (Bertolini, 1891) (Anthozoa: Zoantharia: Gerardiidae). - Vieraea 24, 153-164.

Ortea, J. \& Martinez, E., 1991. Molluscos Opisthobranchios de Cabo Verde: Anaspidea (Aplysiomorpha). - Publ. Ocas. Soc. Port. Malac. 15, 17-42.

Ortea, J., Valdés, A. \& García-Gómez, J. C., 1996. Revisión de las especies atlánticas de la familia Chromodorididae (Mollusca: Nudibranchia) del grupo cromático azul. - Avicennia (supl.) 1, 1-165.

Pérez Sánchez, J. M. \& Moreno Batet, E., 1991. Invertebrados Marinos de Canarias. Ediciones del Cabildo Insular de Gran Canaria, Las Palmas, 335 pp.

Poppe, G. T. \& Goto, Y., 1991. European seashells. Hemmen, Wiesbaden 1, 1-352.

Quignard, J. P. \& Pras, A., 1986. Labridae. In: Fishes of the North-eastern Atlantic and the Mediterranean. Ed. by P. J. P. Whitehead, M. L. Bauchot, J. C. Hureau, J. Nielsen \& E. Tortonese. UNESCO, Paris, 1473 pp.

Rankin, J. J., 1956. The structure and biology of Vallicula multiformis, gen. et sp. nov. a platyctenid ctenophore. - J. Linn. Soc. (Zool.) 43, 55-71.

Rogers, A. D. \& Nash, R. D. M., 1996. A new species of Ochetostoma (Echiura, Echiuridae) found in the Azores, with notes on its ecology. - J. mar. biol. Ass. U. K. 76, 467-478.

Schinner, G. O., 1993. Burrowing behaviour, substrate preference and distribution of Schizaster canaliferus (Echinoidea Spatangoida) in the northern Adriatic sea. - Mar. Ecol. 14, 129-145.

Silva, D. P. de, 1990. Sphyraenidae. In: Check-list of the fishes of the eastern tropical Atlantic. Ed. by J. C. Quéro, J. C. Hureau, C. Karrer, A. Post \& L. Saldanha. UNESCO, Lisbon, 1492 pp.

Sterrer, W., 1986. Marine fauna and flora of Bermuda. Wiley, New York, $742 \mathrm{pp}$.

Stock, J. H., 1994. A new member of the family Bogidiellidae (Crustacea, Amphipoda) from poikilohaline waters of Madeira. - Bocagiana 171, 1-8.

Templado, J., Guerra, A., Bedoya, J., Moreno, D., Remón, J. M. Maldonado, M. \& Ramos, M. A., 1993. Fauna marina circalitoral del Sur de la Peninsula Iberica. Museu Nacional de Ciencias Naturales. Madrid, $181 \mathrm{pp}$.

Thompson, T. E., 1988. Molluscs: Benthic opisthobranchs. Brill, Leiden, 356 pp. (Synopses of the British Fauna N.S. 8.).

Trowbridge, C. C., 1995. New Zealand opisthobranchs associated with the low intertidal, crustose green alga Codium convolutum. - Veliger 38, 116-125.

d'Udekem d' Acoz, C., 1996. Description of Periclimenes wirtzisp.nov., a new pontoniine shrimp from Madeira and Azores, with a checklist of eastern Atlantic and Mediterranean Pontoniinae (Crustacea, Decapoda, Caridea). - Bull. Inst. r. Sci. nat. Belg. (Biol.) 66, 133-149 
Twelve invertebrate and eight fish species new to the marine fauna of Madeira 207

Valdés, A., Ortea, J., Avila, C. \& Ballesteros, M., 1996. Review of the genus Dendrodoris Ehrenberg, 1831 (Gastropoda: Nudibranchia) in the Atlantic ocean. - J. moll. Stud. 62, 1- 31.

Watson, R. B., 1897. On the marine mollusca from Madeira; with descriptions of thirty-five new species, and an index-list of all the known sea-dwelling species of that island. - J. Linn. Soc. (Zool.) 26, 18-320.

Wirtz, P., 1994. Three shrimps, five nudibranchs, and two tunicates new for the marine fauna of Madeira. - Bolm Mus. Mun. Funchal 46 (257), 167-172.

Wirtz, P., 1995a. Unterwasserführer Madeira Kanaren Azoren Wirbellose - Underwater Guide Madeira Canary Islands Azores Invertebrates. Naglschmid, Stuttgart, 248 pp.

Wirtz, P., 1995b. One vascular plant and ten invertebrates new for the marine flora and fauna of Madeira. - Arquipélago. Life Mar. Sci. 13 A, 119-124.

Wirtz, P., 1996a. Neue Keulenseescheiden von Madeira. - Aquar. Terrar. Z. 1996, 162-164.

Wirtz, P. 1996b. Die Grundeln von Madeira. - Aquar. Terrar. Z. 1996, 236-239.

Wirtz, P. \& Martins, H., 1993. Notes on some rare and little known marine invertebrates from the Azores - with a discussion of the zoogeography of the area. - Arquipelago. Life Mar. Sci. 11 A, 55-63.

Wirtz, P., Müller, B. \& Nahke, P., 1988. The Caribbean shrimp Tuleariocaris neglecta Chace 1969 found in association with Diadema antillarum at Madeira, and two new records of decapod crustaceans from the Cape Verde islands. - Cour. Forsch. Inst. Senckenberg 105, 169-171.

Wittmann, K. \& Wirtz, P. A first inventory of the mysid fauna (Crustacea: Mysidacea) in coastal waters of the Madeira and Canary Archipelagos. - Bolm Mus Municip. Funchal (in press).

Zibrowius, H., 1985. Gerardia savaglia (Cnidaria: Anthozoa: Zoantharia) - nouvel hote de Balssia gasti (Crustacea: Decapoda: Pontoniinae). - Rapp. P.-v. Réun. Commn int. Explor. scient. Mer Méditerr. 29, 349-350. 